\title{
The Best of All Possible Worlds (or Pretty Darn Close)
}

\author{
Reinier Kraakman†
}

Marcel Kahan and Edward Rock's Article, How I Learned to Stop Worrying and Love the Pill: Adaptive Responses to Takeover $L a w$, captures an intuition that has come to dominate the middle ground between supporters and critics of Delaware's takeover jurisprudence. This is the view that management's discretion to defeat hostile takeovers under Delaware law just does not matter much today. The reason is not that the current law is right-or wrong. Rather it is because offsetting developments within the corporation-option compensation and active boards-have made managers far more receptive to selling their companies today than they were during the turbulent 1980s.

Kahan and Rock present a stylized history of the takeover market in three parts. First there was the big bang, an exogenous shock in the early 1980s that sharply increased hostile takeovers. This wave of hostile takeovers lasted only a few years, however. It soon was followed by a second period in which takeover activity-and hostile takeovers in particular-fell precipitously. Although the economy was largely responsible for this change, legal and corporate governance developments also contributed to it. During the mid- and late 1980s, state legislatures adopted antitakeover legislation, while management and its allies experimented with defensive tactics. Management's efforts at self-help culminated in the poison pill, which the Delaware Supreme Court blessed, at least provisionally, in 1986. The pill placed management back in the catbird seat, able to block hostile takeovers without seeking shareholder approval. But the system still was not in equilibrium. There was no turning back the clock; shareholders still wanted the takeover premia that accompanied a robust flow of deals. Equilibrium returned to the system only in the third and final period, beginning around 1992, when option compensation plans and independent boards of directors combined to spark a new wave of friendly acquisitions that profited both shareholders and the managers of target companies.

$\dagger$ Ezra Ripley Thayer Professor of Law, Harvard Law School.

69 U Chi L Rev 871 (2002). 
In the authors' view, this history teaches us that things work themselves out. Evolving compensation and governance policies have largely neutralized the board's power to block hostile takeovers. Today, target managers and shareholders collaborate for mutual benefit. Pills and staggered boards are controversial only if we fail to realize that they do not function in a vacuum. Legal change that empowers corporate boards to resist takeovers is offset by "adaptive" change, such as increases in option compensation, that encourage target boards to put aside defenses and accept fairly-priced takeovers. What matters is this entire ensemble of effects and countereffects, not its isolated components.

I am persuaded by many - but not all-of the lessons that Kahan and Rock draw from this history. First, they are undoubtedly right to remind us that effects of law depend on the responses of the participants in a market such as the market for corporate control. It will not do to address the effects of takeover law separate from compensation policy and corporate governance (or to analyze doctrinal developments "ceteris paribus" rather than "mutatis mutandis," as the authors put it).

Second, I suspect that the authors also are right in their conjecture that dramatic increases in option compensation have encouraged target managers to part with their companies more easily in the 1990s than in earlier decades. In fact, together with a colleague, John Coates, I am currently investigating the relationship between option compensation and the probability that companies were acquired during the 1990s. We expect to find more or less what Kahan and Rock would predict: a positive relationship between management's decision to sell a company and the size of its payout in the event of a sale (relative to management's expected compensation if the company remains independent). Thus far, however, we have not been able to demonstrate this relationship beyond cavil. The value of CEO options is clearly correlated with the mean probability that an S\&P 1500 firm was ac-

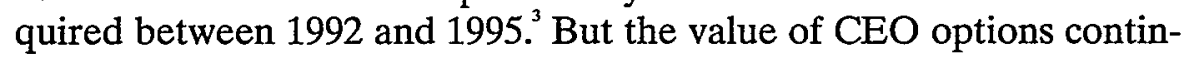
ued to accelerate from 1995 through 1998, while mean acquisition probabilities remained roughly constant. ${ }^{4}$ Moreover, concluding that

2 We are working with Compustat's Execucomp database for the Standard \& Poor's ("S\&P") 1500 companies between 1992 and 1998 and the Thomson Financial Securities (formerly SDC) M\&A database.

3 From 1992 until 1995, the annual probability that any single S\&P 1500 firm was acquired in a takeover rose almost linearly from 0.9 percent to 4.2 percent, while the mean value of total CEO options, estimated by the Black-Scholes model, increased from $\$ 3.4$ million to $\$ 5.6$ million.

4 The mean value of CEO options increased from $\$ 5.6$ million in 1995 to $\$ 15.1$ million in 1998-a nearly threefold increase. By contrast, the annual probability that an S\&P 1500 firm would be acquired increased only marginally from 4.2 percent to 4.5 percent. 
option values influenced acquisition probabilities within any given year is simply not possible at this early stage of our investigation.

Finally, I agree with Kahan and Rock that Delaware corporate law has long embraced a norm of "bilateral," board-and-shareholder participation in making basic corporate decisions-and that the Delaware courts should be urged to adhere to this norm. I differ from Kahan and Rock in this area principally on secondary matters: whether the prevailing bilateral model is optimal for shareholders, and whether the Delaware courts actually follow the bilateral model in the takeover case law.

Despite these areas of agreement, however, I would like to flag three areas in which I have reservations or disagreements with the Kahan and Rock Article. I address each of these below.

\section{OPTION COMPENSATION IN THE 1990s WAS NOT AN “ADAPTIVE DEVICE" SPECIFICALLYTARGETED AT DELAWARE TAKEOVER LAW}

Kahan and Rock describe the takeover market as a kind of game between shareholders and managers. Managers move first by adopting takeover defenses; shareholders, who are too weak to do otherwise, respond with large carrots (stock options) and small sticks (independent directors). But this metaphor of a game seems misleading in two respects.

As a descriptive matter, neither growth of option compensation nor the influence of independent directors seems like anyone's calculated move in a simple game. Instead, both were long-term trends or movements, with many proponents and detractors-but with no single collective subject. The movement to add independent directors dates back to the 1960 s, well before recent interest in compensation; the sharp rise in option compensation began in the 1990s. In both cases, momentum built slowly. Boards copied boards, and boards increased salaries, one at a time. Board positions in the United States shifted to independent directors over a period of decades, just as they now are shifting in foreign jurisdictions such as the United Kingdom.

Still more important, insofar as increased option compensation or board independence did respond to shareholder concerns, shareholders are unlikely to have targeted these changes at legal impediments to hostile takeovers. Takeovers affect only a small fraction of public companies annually, and there are devices, such as golden parachutes, that are much more precisely tailored to management's acquisition incentives than are options.

Rather, to the extent that institutional shareholders encouraged boards to adopt changes in pay and governance during the 1990s, their most likely goal was to increase global management performance, irrespective of whether a given company was the potential acquisition 
target. If Delaware takeover law played a role in fueling option compensation, it probably was indirect. Institutional shareholders might have perceived the steep decline in hostile takeovers at the outset of the 1990s as weakening management's performance incentives in general. Thus, they might have reacted to the loss of this global takeover "stick," by offering the new and costly carrot of enhanced performance compensation to more or less all corporate managers.

Put differently, high-powered option compensation no doubt was meant to induce managers to maximize shareholder value in general, but I doubt it ever was intended to offset managerial resistance to takeovers in particular. To the extent that options had the effect of encouraging friendly deals, I suspect the effect was an unintended and incidental consequence of a much more diffuse effort to encourage management performance. The contractual provision in most option plans that permits options to vest upon a change of control is not evidence to the contrary. If this provision were designed to induce takeovers rather than to protect option values, it would be restricted to a company's top managers. Instead, it typically extends its protection to all participants in option plans, from the CEO to the worker on the shop floor.

\section{OPTION-DRIVEN FRIENDLY DEALS ARE NOT NECESSARILY SUBSTITUTES FOR HOSTILE AND FRIENDLY DEALS OF THE 1980S}

My second reservation about the Kahan and Rock Article concerns what I take to be their implicit assumption that all deals have roughly similar effects on shareholder welfare. In fact, there is reason to believe that option-driven friendly deals may not be very good substitutes for hostile takeovers.

In the first instance, friendly deals are not disciplinary takeovers, as I already have noted. Arguably, the hostile takeovers of the 1980s motivated managers in general to maximize shareholder value. If so, this effect was lost in the 1990s, as target managers came increasingly to control whether or not their companies would be acquired. Perhaps option compensation in the 1990s substitutes for the lost incentive of the disciplinary takeover. If so, however, the cost of allowing target managers to defeat hostile takeovers is not merely the cost of "bribing" a small percentage of CEOs each year to accede to friendly takeovers, as Kahan and Rock sometimes seem to imply. Rather, the cost of legal change that allows target managers to block hostile takeovers is the sum of all inducements paid to all managers to compensate for the lost incentive effects of hostile takeovers. This sum is much larger than the cost of persuading a relatively small number of managers each year to go peaceably to the auction block. 
In addition, there are many more obscure consequences of shifting control over deals from bidders to target managers. Thus, it is by no means clear what the incentive effects of large option payouts for target managers really are. Are target managers with generous option plans motivated to seek an acquisition partner as soon as possible in order to cash out while they can? Might skilled managers reduce shareholder value by selling out too soon rather than seeking to entrench themselves? Or are target managers motivated to bide their time, perhaps until retirement, in the expectation that they always will have still more options to cash out at a later date? And how does the possibility of cashing out a treasure trove of stock options in a future acquisition affect a target manager's incentives to maximize shareholder value today? If exercise prices on options are set to market price when options are issued, might a target manager prefer low share prices while he accumulates options in the expectation of realizing a larger gain when the company is sold? I do not know how important such perverse incentives are; I mention them only to emphasize that option-induced deals are not substitutes for the hostile or friendly deals of the 1980s. Whether they are better or worse for shareholders remains an open question.

\section{III. “ADAPTIVE DEVICES" IN THE TAKEOVER MARKET HAVE No CLEAR IMPLICATIONS FOR LEGAL POLICY}

The Kahan and Rock model of adaptive devices has no clear implication for legal policy, other than the suggestion in the title of their Article that we should "stop worrying" because the law is less important than we might previously have believed. All of the old disputes about takeover policy still remain, it's just that they matter less if Kahan and Rock are right. Curiously, however, the authors do not conclude on this plausible, if oddly discomforting, point. Rather, they press on to join issue in the traditional takeover debate by arguing that the Delaware Supreme Court has gotten takeover law more or less right. In particular, Kahan and Rock argue that the Court has adopted a norm of bilateral decisionmaking, in which both the board and shareholders must participate in fundamental corporate decisions such as a sale of the company. Moreover, they claim that the norm of bilateral decisionmaking is more likely to increase shareholder welfare than the competing norms of unilateral decisionmaking, whether by the shareholders or by the board of directors.

Both of these claims about legal policy are, in my view, separable from the main part of the Kahan and Rock Article-and perhaps for this reason not very vigorously defended. The question whether shareholders are the best judges of their own welfare lies at the heart of the traditional takeover debate. If they are, a good case can be 
made that unilateral shareholder decisionmaking on acquisition questions is much more likely to increase shareholder welfare than a bilateral rule that permits boards to veto shareholder choice. Kahan and Rock recite the familiar arguments about board expertise and shareholder collective action problems to reach an opposite conclusion, but they do not explore how these problems might be resolved within the framework of shareholder choice.

Equally noteworthy, Kahan and Rock's claim that Delaware's takeover jurisprudence has adopted a bilateral decisionmaking norm is itself contestable. To cite an example, a board of a public company can protect a stock-for-stock merger against a competing offer with a poison pill and subsequently leave the combined firm without ever facing a shareholder vote. Similarly, a target firm with a staggered board and a poison pill can in theory fend off hostile bidders indefinitely, providing that no hostile bidder can afford to pursue its offer through two annual proxy contests. Both of these examples would seem to violate the bilateral decisionmaking norm. The best explanation of the twists and turns in Delaware's takeover law is not bilateralism in my view, but board paternalism - a consistent policy of supporting the board's judgment over shareholder choice whenever there is any ambiguity about where the best interests of shareholders lie. I develop this point in a separate article and will not expand upon it here. I mention it only because in that article I embrace bilateral decisionmaking, as previously described by Kahan, as a feasible basis for reforming Delaware takeover law rather than as an accurate description of its existing thrust.

My responses to the legal policy conclusions of the Kahan and Rock Article are incidental to its main argument, however. I predict this important Article will come to define the middle ground in the takeover debates of the next decade. Its fundamental observations about the effects of law on market participants who are able to react are unquestionably correct.

5 See Bernard Black and Reinier Kraakman, Delaware's Takeover Law: The Uncertain Search for Hidden Value, $96 \mathrm{Nw}$ U L Rev 521, 522-25 (2002) (contending that Delaware courts operate under the assumption that only the directors, and not the shareholders, know the firm's true economic value).

6 See Marcel Kahan, Paramount or Paradox: The Delaware Supreme Court's Takeover Jurisprudence, $19 \mathrm{~J}$ Corp L 583, 600 (1994) (arguing that Delaware courts have tried to improve the process of the target board's decisionmaking so as to reduce potential conflicts of interest while also preserving shareholders' ultimate power to override a board's rejection of an offer). 


\title{
SYMPOSIUM: \\ MANAgEMENT AND CONTROL \\ OF THE MODERN BUSINESS CORPORATION
}

\begin{abstract}
CORPORATE CONTROL TRANSACTIONS
Market Evidence in Corporate Law................... Daniel R. Fischel 941

Commentary on Fischel ...............................................Isaac Corre 963

Discussion moderated by Douglas G. Baird
\end{abstract}

The Case Against Board Veto

in Corporate Takeovers.......................... Lucian Arye Bebchuk 973

Pills, Polls, and Professors Redux............................Martin Lipton 1037

Discussion moderated by Lisa Bernstein

The Great Takeover Debate: William T. Allen

A Meditation on Bridging Jack B. Jacobs \&

the Conceptual Divide ...................................... Leo E. Strine, Jr. 1067

Discussion moderated by Thomas A. Cole 


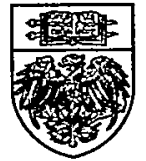

